\title{
IDENTIFYING THE DEGREE OF LUMINESCENCE SIGNAL BLEACHING IN FLUVIAL SEDIMENTS FROM THE INNER MONGOLIAN REACHES OF THE YELLOW RIVER
}

\author{
FUQIANG LI ${ }^{1}$, BAOTIAN PAN ${ }^{1}$, ZHONGPING LAI $^{2}$, HONGSHAN GAO ${ }^{1}$ and XIANJIAO OU ${ }^{3}$ \\ ${ }^{I}$ Key Laboratory of Western China's Environmental Systems (Ministry of Education), College of Earth and Environmental Sciences, \\ Lanzhou University, Lanzhou, 730000, China \\ ${ }^{2}$ School of Earth Sciences, China University of Geosciences, Wuhan, 430074, China \\ ${ }^{3}$ School of Geography and Tourism, Jiaying University, Meizhou, Guangdong, 514015, China
}

Received 5 September 2017

Accepted 17 January 2018

\begin{abstract}
The partial bleaching of the luminescence signal prior to deposition results in age overestimation, and can be a problem in delineating fluvial evolution within an OSL chronological framework. The Inner Mongolian reaches of the Yellow River are characterised by a high sediment load and complex sources of sediments. To test the incomplete bleaching occurring in this type of environment, the residual doses and the luminescence signal characteristics of different particle size fractions from 14 modern fluvial sediment samples were investigated. Furthermore, 26 OSL ages derived from drilling cores were compared with 11 radiocarbon ages. Our results show that the residual equivalent doses principally range between 0.16 and 0.49 Gy for silt grains, and between 0.35 and $3.72 \mathrm{~Gy}$ for sand grains of modern samples. This suggests that medium-grained quartz has been well bleached prior to deposition, and is preferable to coarse-grained quartz when dating fluvial sediments in this region. The results also show that the $D_{e}$ values of coarse-grained fractions display a stronger correlation with distance downstream. In addition, a comparison of OSL and radiocarbon ages from drilling cores establishes further confidence that any initial bleaching of these sediments was sufficient. As a result, we believe that the studied fluvial samples were well bleached prior to deposition.
\end{abstract}

Keywords: Yellow River, OSL dating, partial bleaching, modern fluvial sediments, ${ }^{14} \mathrm{C}$ age.

\section{INTRODUCTION}

OSL dating is now increasingly being used to determine the timing of the deposition of fluvial sediments (e.g. Wallinga, 2002; Jain et al., 2004; Rittenour, 2008). This technique has the benefit of being able to directly date the depositional time of the fluvial sediments, using quartz and feldspar (the main constituents of fluvial sediments) as dating materials. The technique has been suc-

Corresponding author: F.Q. Li e-mail: lifq13@1zu.edu.cn cessfully used to date sediments over timescales ranging from several decades to several hundreds of thousands of years (e.g. Liu et al., 2011; Lai and Ou, 2013). The OSL dating method relies on the luminescence signal acquired during the preceding burial history having been removed by light exposure (zeroing) prior to deposition (Rittenour, 2008). The rate and completeness of the bleaching depends on both environmental factors and sample properties (Rhodes, 2011). When clean quartz grains are exposed directly to sunlight, the OSL signal is reduced to a negligible level within a few seconds (Wintle, 1997; Aitken, 1998). The OSL signal is also affected by the degree of the attenuation of light through the water column, water depth, the mode of sedimentary transport, 
transport distance, the previously non-bleached sediments from the erosion of older deposits and river banks in different fluvial sedimentary environments, etc. (Jain et al., 2004; Rittenour, 2008; Schielein and Lomax, 2013). Additionally, fluvial systems in arid regions, most probably due to the high sedimentary load and the rapid transport experienced during intense flooding, generate the most rapid and intense sedimentary deposition (Porat et al., 2010). For these reasons, the assumption made in OSL dating that the signal has been completely zeroed prior to deposition is not always applicable to fluvial deposits. We therefore have to be able to demonstrate that samples have been bleached prior to deposition.

A number of approaches have been proposed to test the completeness of bleaching prior to deposition in the past. First, one could determine the ages and assess the residual signals present in modern (recently-deposited) samples from a range of contexts, and then use these modern analogues to assess the degree of bleaching in older materials which have experienced the same depositional conditions (e.g. Rhodes and Bailey, 1997; Jain et al., 2004; Singarayer et al., 2005; Hu et al., 2010). Second, when samples of a known age are dated, and a comparison is made between the independently-measured and OSL ages derived from specific environments, it can be reasonably assumed that when the OSL ages are in agreement with the independent ages, the OSL sample may be judged as having been sufficiently well bleached (e.g. Jain et al., 2004; Olley et al., 2004). Third, a comparison can be made between the different depositional energies, grain sizes, and mineralogy of closely spaced OSL samples (e.g. Richards et al., 2000). A fourth method uses the forms of the dose distributions to assess the completeness of bleaching (e.g. Olley et al., 1999). Fifth, a comparison can be made between the scatter patterns of $\mathrm{D}_{e}$ values and the sensitivity-adjusted natural signal $\left(\mathrm{L}_{\mathrm{n}} / \mathrm{T}_{\mathrm{n}}\right)($ e.g. $\mathrm{Li}, 2001)$, and any relation between the two controls assessed. A sixth method focuses on the reconstruction of the likely patterns of sedimentary transport for different environments, using simple geomorphic models which can then be used to predict the optimal bleaching regimes (e.g. Schielein and Lomax, 2013). A seventh approach uses single-grain OSL measurements to assess the completeness of bleaching (e.g. Duller, 2008). Although each of these seven methods has its own drawbacks, a convergence of the results obtained from different approaches should give a reliable assessment of the complete zeroing of the trapped charge prior to deposition (Jain et al., 2004).

The Yellow River is famous for its high sedimentary load. It is the second largest river in the world in terms of sedimentary load (Milliman and Meade, 1983). The high turbidity of the Yellow River's water limits light penetration, potentially causing the partial bleaching of OSL signals in suspended and bedload sediments (Ditlefsen, 1992). The Inner Mongolian reaches of the Yellow River are characterised by desert environments which extend along either side of the river channel, as well as by high sedimentary loads, by severe sedimentary siltation, and by extensive river channel migration (Ta et al., 2008; Yao et al., 2011; Wang et al., 2012; Pan et al., 2015). The primary sediment source comes from the upper reaches, aeolian sediments from wind-blown sources, and dunes eroded by lateral river-channel shifts, tributary confluences and sandy bank failures (Ta et al., 2011; Pan et al., 2015). Therefore, the sedimentary sources and the depositional process are both highly complex, and their bleached and non-bleached material can be carried into the mainstream, making it potentially very difficult to date fluvial sediments using OSL dating. In this study, our aim is to determine the residual OSL signals in modern fluvial sediments and to make a comparison between OSL ages and AMS ${ }^{14} \mathrm{C}$ (radiocarbon) ages to test the completeness of the bleaching of the older OSL samples extracted from drilling cores.

Numerous studies have tested the residual signals found in modern fluvial sediments (Jain et al., 2004; Fuchs et al., 2005; Singarayer et al., 2005; Vandenberghe et al., 2007; Hu et al., 2010). These have made use of modern analogues to help assess the degree of bleaching in older fluvial sediments (Jain et al., 2004; Singarayer et al., 2005). However, not all modern samples constitute good analogues for the bleaching of older deposits (Rittenour, 2008), making it necessary to fully interpret the sample context (Rodnight et al., 2006). ${ }^{14} \mathrm{C}$ dating offers the most precise dating method for fluvial systems (Blong and Gillespie, 1978; Murray and Olley, 2002; Jain et al., 2004). However, this method of dating fluvial processes has been employed relatively infrequently due to the widespread absence of organic carbon for ${ }^{14} \mathrm{C}$ dating in dry environments. The ${ }^{14} \mathrm{C}$ age range (40-0 ka BP) and problems concomitant with the reworking of old carbon in many fluvial types of sediment (Wallinga, 2002; Cunningham and Wallinga, 2012) have also presented certain difficulties in using this method. Nonetheless, the ${ }^{14} \mathrm{C}$ dating method continues to show its effectiveness in providing alluvial stratigraphic ages (DeLong and Arnold, 2007), and has been commonly used for independently confirming OSL ages (Rodnight et al., 2006). It has also been used to help assess the degree of OSL signal bleaching in older fluvial sediments (Colls et al., 2001; Murray and Olley, 2002; Jain et al., 2004).

\section{THE STUDY AREA AND SAMPLE COLLECTION}

Our study area was located along the Inner Mongolian reaches of the Yellow River, starting at Shizuishan (the Ningxia Autonomous Region), and ending at Hekou Town (the Inner Mongolia Autonomous Region). The total river-channel length was $673 \mathrm{~km}$ (Fig. 1). Due to the shallow gradient, a meandering channel, loose riverbed materials, a high sedimentary load and surrounding vast alluvial plains (the Hetao Plain) (Hou, 1996), these meandering reaches of the Yellow River experience high 
lateral erosion, which in turn leads to frequent changes in the course of the river channel (Li et al., 2003). During these changes, the riverbed also undergoes serious siltation. The riverbed has risen markedly, and a nearly $150 \mathrm{~km}$ channel has become a "hanging river" in recent decades (the riverbed is higher than the land outside the artificial levees) (Wang et al., 2012; Shi, 2010; Liu et al., 2012). The heavy siltation, along with the rapid and frequent changes in the course of the river channel, have consequently caused substantial social, economic and environmental problems (Ta et al., 2008; Wu et al., 2006). Up-river, the Yellow River flows through the Chinese Loess Plateau (CLP) and the Tengger and Hedong deserts. It is bordered by the Ulan Buh and Hobq deserts, the Ten Great Gullies (through which ten tributaries enter the main stream of the Yellow River) in the south of its Inner Mongolian reaches (Ta et al., 2003). These tributaries originate from the centre of the Ordos Plateau (which is also the rainstorm centre of the Ordos Plateau), and then flow through the Hobq Desert (Feng and Zhang, 2008) towards the Yellow River. The riverbeds have an average gradient of $0.10 \%$, and are com- posed of loose silt. This region is characterised by a continental climate, and is located along the margins of the East Asian Monsoon (EAM) belt. The climate in this region is dry, with a low and unevenly distributed annual precipitation (MAP) ranging from 150 to $363 \mathrm{~mm}$, and a potential evapotranspiration (ET) of 1000-2000 mm per annum (Yao et al., 2011; Pan et al., 2015).

Previous studies conducted in this area have mainly focused on the evolution of river channel deposition during the past 50 years. These studies have been principally based on the interpretation of sectional and hydrological data (Ta et al., 2003, 2008; Wang et al., 2012; Yao et al., 2011). The lack of any consistent dating has severely hindered the use of fluvial archives. Consequently, there are few chronological constraints on the long-term evolution of the Yellow River in this region. The majority of studies have focused on the paleolake covering the Hetao Plain during the Late Pleistocene (e.g. Chen et al., 2008). As a result, the difficulties inherent in determining the absolute ages of river processes have become a key stumbling block in the research into long-term river changes. To counter these difficulties, we drilled 12 cores (each

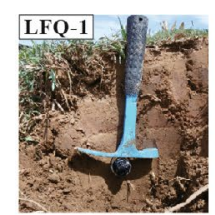

$106^{\circ} \mathrm{E}$
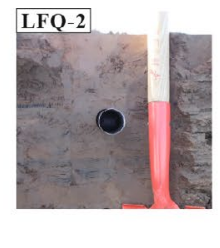
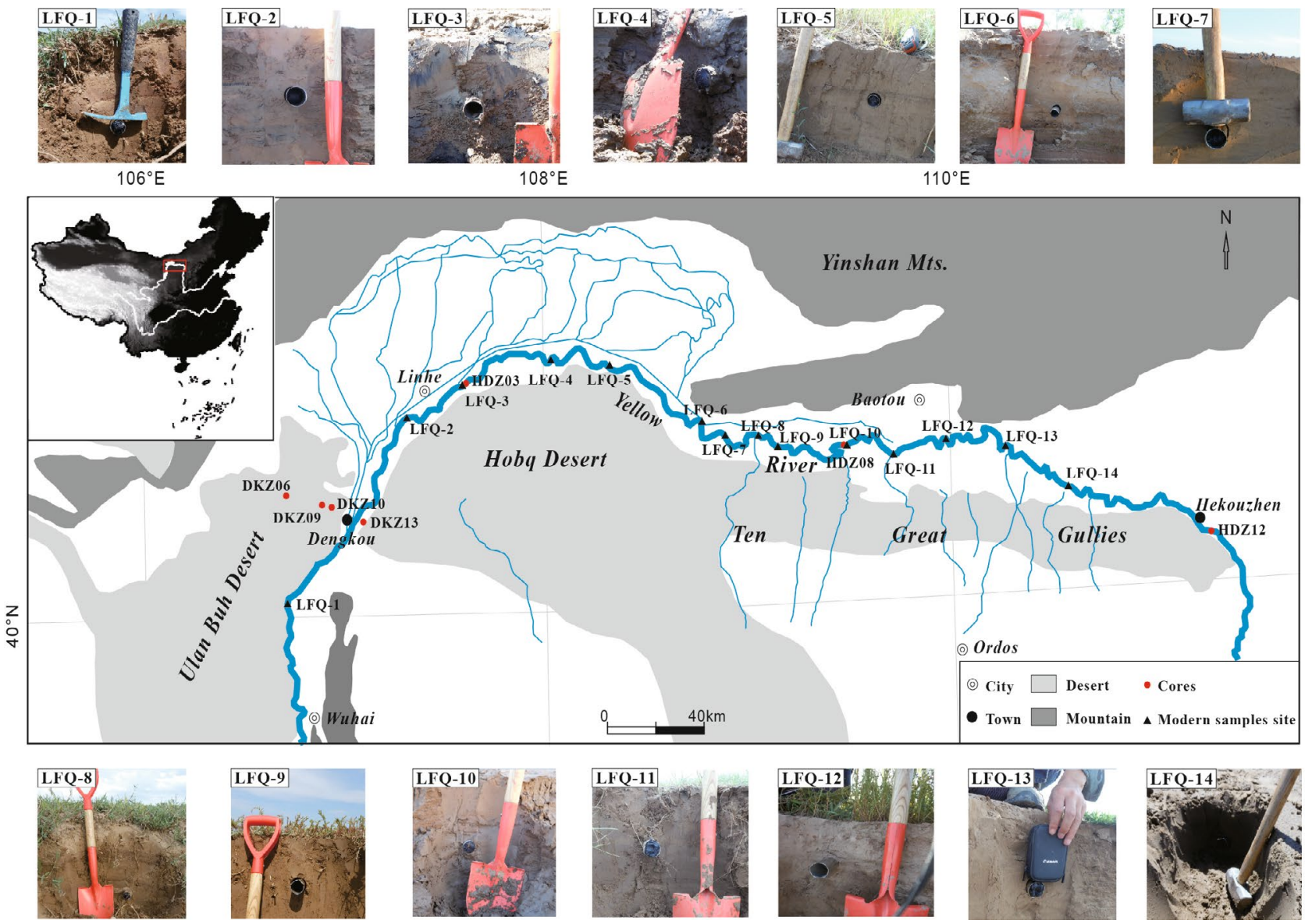

$110^{\circ} \mathrm{E}$

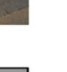


$\sim 20 \mathrm{~m}$ deep) along an east-west transect from Shizuishan to Hekou Town along the Yellow River channel, and then 28 cores along three transects of the Hetao Plain (including 14 in Dengkou County, eight in Tumote County and six in Zhonghexi Town), in an attempt to provide a high resolution record of the long-term evolution of the Yellow River channel sedimentation. The drilling recovery rate for each core was $>85 \%$. We divided each core into $5 \mathrm{~cm}$ intervals before attempting at any preliminary description of the composition and structure of the sedimentary record. Three to five OSL samples per core were extracted in tubes from any silt and fine sand sections found, before being transported to the laboratory for analysis in opaque anti-sunlight bleaching containers. Additionally, organic material and plant residues were collected from seven cores for ${ }^{14} \mathrm{C}$ dating. The 14 modern samples used in this study were collected from a recent sandy alluvium deposited on the fluvial channel along the Inner Mongolian reaches of the Yellow River by hammering steel tubes $(\sim 30$-cm-long cylinders with a diameter of $\sim 4 \mathrm{~cm}$ ) into freshly cleaned vertical sections. We ensured that the samples were extracted from a depth of 15 to $20 \mathrm{~cm}$ below the surface in order to avoid sampling the topmost horizon, which has been affected by human activity (Fig. 1).

\section{METHODOLOGY}

\section{OSL dating}

\section{Sample preparation and measurements}

All OSL samples were opened under a subdued red light in the luminescence-dating laboratory. Minerals were extracted from the unexposed middle parts of the cores and tubes for $\mathrm{D}_{\mathrm{e}}$ determination. All raw samples were treated with $10 \% \mathrm{HCl}$ and $20 \% \mathrm{H}_{2} \mathrm{O}_{2}$ to remove carbonates and organic matter. For modern samples, Grain size fractions of medium fraction $(38-63 \mu \mathrm{m})$ and/or coarse fractions $(63-90,63-150,90-150,150$ $200 \mu \mathrm{m})$ were extracted by wet sieving. The core samples were wet sieved to obtain the medium (MG, 38-63 $\mu \mathrm{m})$ and coarse $(\mathrm{CG}, 90-125 \mu \mathrm{m})$ fraction. The 38-63 $\mu \mathrm{m}$ fraction was etched with $35 \%$ fluorosilicic acid for about two weeks to dissolve feldspars (Lai and Wintle, 2006; Lai et al., 2007a; Roberts, 2007). Then, each coarse $\mu \mathrm{m}$ fraction $(>63 \mu \mathrm{m})$ was treated with $40 \% \mathrm{HF}$ for $45 \mathrm{~min}$ to remove feldspars and the alpha-irradiated outer layer $(\sim 10 \mu \mathrm{m})$. The resulting quartz grains were washed with $10 \% \mathrm{HCl}$ to remove fluoride precipitates. The pre-treated modern sample and core-sample grains were mounted entirely on stainless-steel disks (1 $\mathrm{cm}$ diameter) using silicone oil. In order to avoid any age underestimation caused by feldspar contamination, the purity of the quartz grains was checked using infrared $(830 \mathrm{~nm})$ stimulation. The results show that no obvious IRSL signals were observed in our samples.
OSL signal measurements were made using an automated Risø TL/OSL-DA-15 reader (Markey et al., 1997). $\mathrm{D}_{\mathrm{e}}$ was measured using a combination of the Single Aliquot Regenerative (SAR) dose protocol (Murray and Wintle, 2000) and the Standard Growth Curve (SGC) method (Roberts and Duller, 2004; Lai, 2006; Lai et al., 2007b; Yu and Lai, 2012), namely the SAR-SGC method (Lai and $\mathrm{Ou}, 2013$ ). In this method, four to six aliquots were measured using the SAR protocol to obtain four to six growth curves for each sample, and then averaged to construct an SGC for individual samples (Lai et al., 2007b). Meanwhile, 12 to 16 more aliquots were measured to obtain test-dose-corrected natural signals only; each of these values were then matched using the SGC to obtain a $D_{e}$ value. $D_{e}$ results determined by the SGC appeared to be in close agreement with those obtained using the SAR protocol, i.e. within $10 \%$ for most samples. For the fluvial sediment samples in the Inner Mongolian reaches of the upper Yellow River, the SAR-SGC method was used for $\mathrm{D}_{\mathrm{e}}$ determination. The environmental dose rate was calculated from the measurement of the radioactive element content in the sample, in order to include a small contribution from cosmic rays. For all samples, the uranium (U) and thorium (Th) concentrations, along with the potassium $(\mathrm{K})$ content, were determined using the Neutron Activation Analysis (NAA). For the 38-63 $\mu \mathrm{m}$ fraction, the alpha efficiency value was taken as $0.035 \pm 0.003$ (Lai and Brückner, 2008). The dose rate of the cosmic ray was estimated for each sample as a function of depth, altitude and geomagnetic latitude (Prescott and Hutton, 1994). The water content of core samples was measured in the laboratory. The water content values were mostly $\sim 15 \%$, according to laboratory measurements. As a result, a water content of $15 \pm 5 \%$ was introduced for the calculation of the ages of modern samples.

\section{The preheat plateau and dose recovery}

The preheat plateau test was used to isolate suitable preheat temperatures. The dose recovery test was employed to evaluate the suitability of the SAR protocol. A modern sample (LFQ-07) and a core sample (HDZ03-06) were selected for the preheat plateau test. The test temperatures of the modern samples were set at 180, 200, 220,240 and $260^{\circ} \mathrm{C}$, with four aliquots' being used at each preheat temperature. No significant difference was found between 180 and $240^{\circ} \mathrm{C}$. Thus, a combination of a $200^{\circ} \mathrm{C}$ preheat $(10 \mathrm{~s})$ temperature and a $180^{\circ} \mathrm{C}$ cut heat was chosen for the SAR measurement of modern samples (Fig. 2a). For core sample HDZ03-06, the test temperatures were set at $220,240,260,280$ and $300^{\circ} \mathrm{C}$, whereas the preheat plateau was clearly identified from 220 to $260^{\circ} \mathrm{C}$. Therefore, a preheat temperature of $260^{\circ} \mathrm{C}$ for $10 \mathrm{~s}$ was chosen for both the natural and regenerative doses, and a cut heat of $220^{\circ} \mathrm{C}$ was selected for test doses (Fig. 2c). 


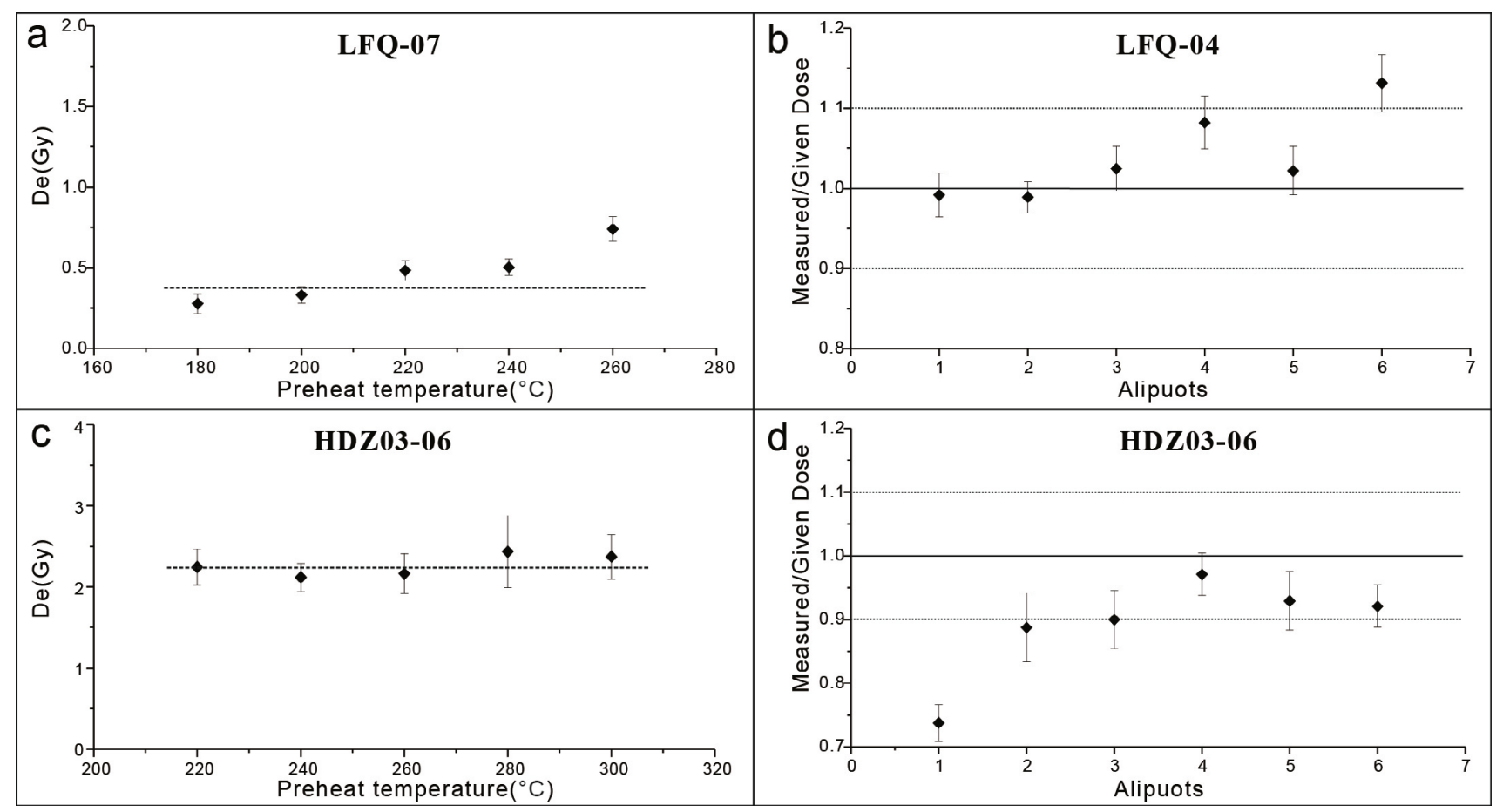

Fig. 2. The results of preheat plateau tests $(a, c)$ and dose recovery tests $(b, d)$. Samples LFQ-07 and LFQ-04 are of modern fluvial sediments; sample HDZ03-06 is from a drilling core.

For the dose recovery test, a new set of six aliquots from each of the two samples (LFQ-04, HDZ03-06) was first bleached with blue LED for $100 \mathrm{~s}$ at room temperature, following which a known dose, which was nearly equal to their natural dose $\left(D_{e}\right)$, was administered, and the same preheat/cut-heat conditions, as employed in the standard SAR measurement protocol, were used. The dose recovery ratios for these two samples are shown in Fig. 2b and Fig. 2d, respectively. The measured -to-given dose ratios were 1.04 and 0.90 (their mean values), falling within the $0.9-1.1$ acceptance range. The given dose was well reproduced, indicating that, in this study, the SAR protocol is suitable for $\mathrm{D}_{\mathrm{e}}$ determination.

\section{AMS ${ }^{14} \mathrm{C}$ dating}

In order to determine an independent chronological control, we compared OSL dates with $\mathrm{AMS}^{14} \mathrm{C}$ dates. Although it was difficult to obtain reliable $\mathrm{AMS}^{14} \mathrm{C}$ dates from fluvial sediments, due to the limited number of ${ }^{14} \mathrm{C}$ samples, the plant residues and a clay layer rich in organic matters found within each core were suitable for ${ }^{14} \mathrm{C}$ dating. $11{ }^{14} \mathrm{C}$ samples from seven cores were dated using the $\mathrm{AMS}^{14} \mathrm{C}$ dating method at the Radiocarbon Dating Laboratory of Peking University and Beta Analytic, Inc. (Miami, FL, USA). ${ }^{14} \mathrm{C}$ dates were calibrated to the calendar year before the present (cal BP) using the
IntCal13 curve (Reimer et al., 2013). Calib Rev 7.0.0 software was used to this end (Stuiver and Reimer, 2013).

\section{RESULTS}

\section{The OSL characteristic and ages of modern samples}

Fig. 3a shows a typical natural OSL decay curve for modern sample LFQ-06. The OSL natural signal exhibits a very low value close to the measurement background, and this signal was rapidly bleached by blue light. Almost all the samples showed similar characteristics. The growth curve of all the modern samples was averaged to construct an SGC (Fig. 3b). The recycling ratios of all the samples were within the 0.9-1.1 acceptance range.

The $D_{e}$ values and OSL apparent ages of different grain sizes for the modern samples are given in Table 1, and the $D_{e}$ values of different grain sizes versus downstream distance obtained are shown in the Fig. 4. The mean $D_{e}$ values of silt grains $(38-63 \mu \mathrm{m})$ for most samples ranged from 0.16 to $0.49 \mathrm{~Gy}$, except for samples LFQ-5 and LFQ-13, which showed $\mathrm{D}_{\mathrm{e}}$ values of 0.74 Gy and $1 \mathrm{~Gy}$, respectively, and it appears that no dependence of $\mathrm{D}_{\mathrm{e}}$ with distance downstream was observed. However, for the coarser grains $(63-90,90-150 \mu \mathrm{m})$, the $\mathrm{D}_{\mathrm{e}}$ values showed a larger correlation with distance downstream. It also can be seen from Figs. $\mathbf{4}$ and $\mathbf{5}$ that the modern samples show a general increase in the equivalent dose with an increasing grain size. 


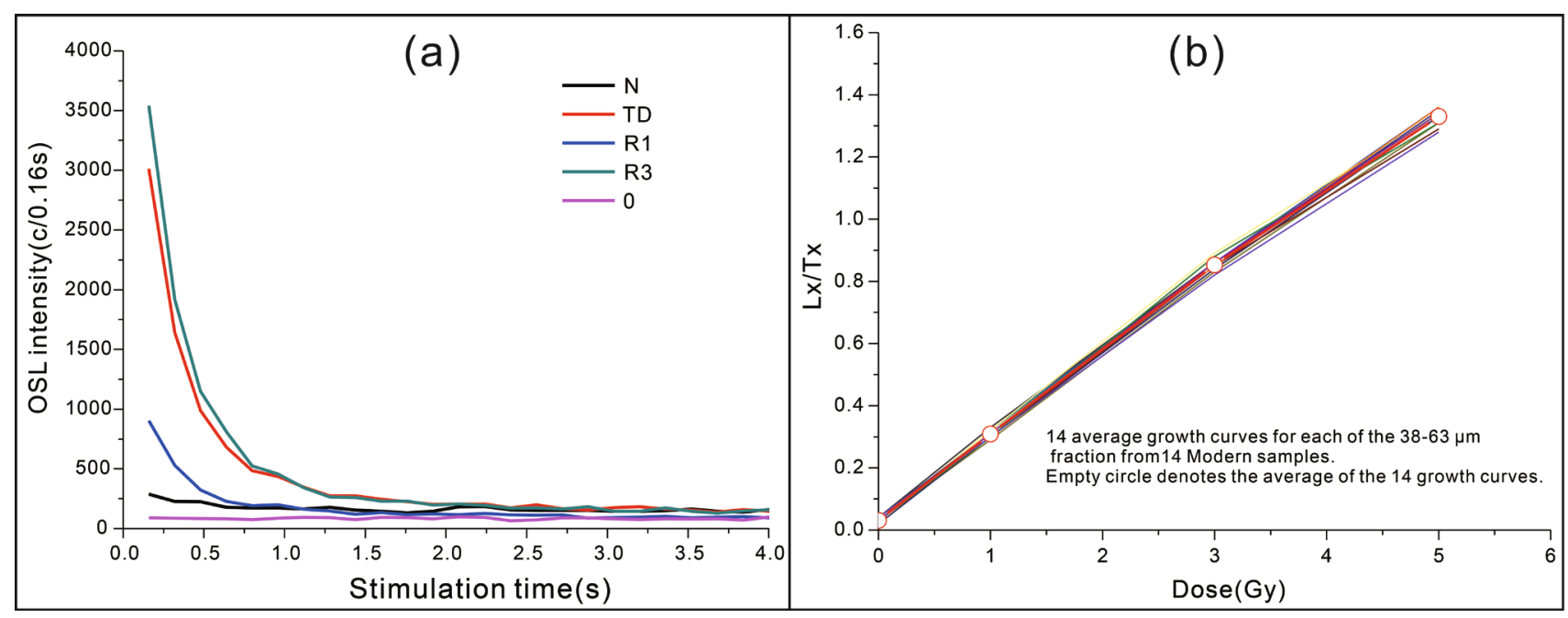

Fig. 3. (a) OSL decay curves for zero (0), natural (N), test (TD, 3.65 Gy), and regeneration doses (R1 and R3, 1 Gy and 5 Gy, respectively) for Sample LFQ-6. (b). The growth curve for each of the modern samples (shown by the black lines); the red line with open circles denotes the average of all the growth curves, which is taken as the standardised growth curve.

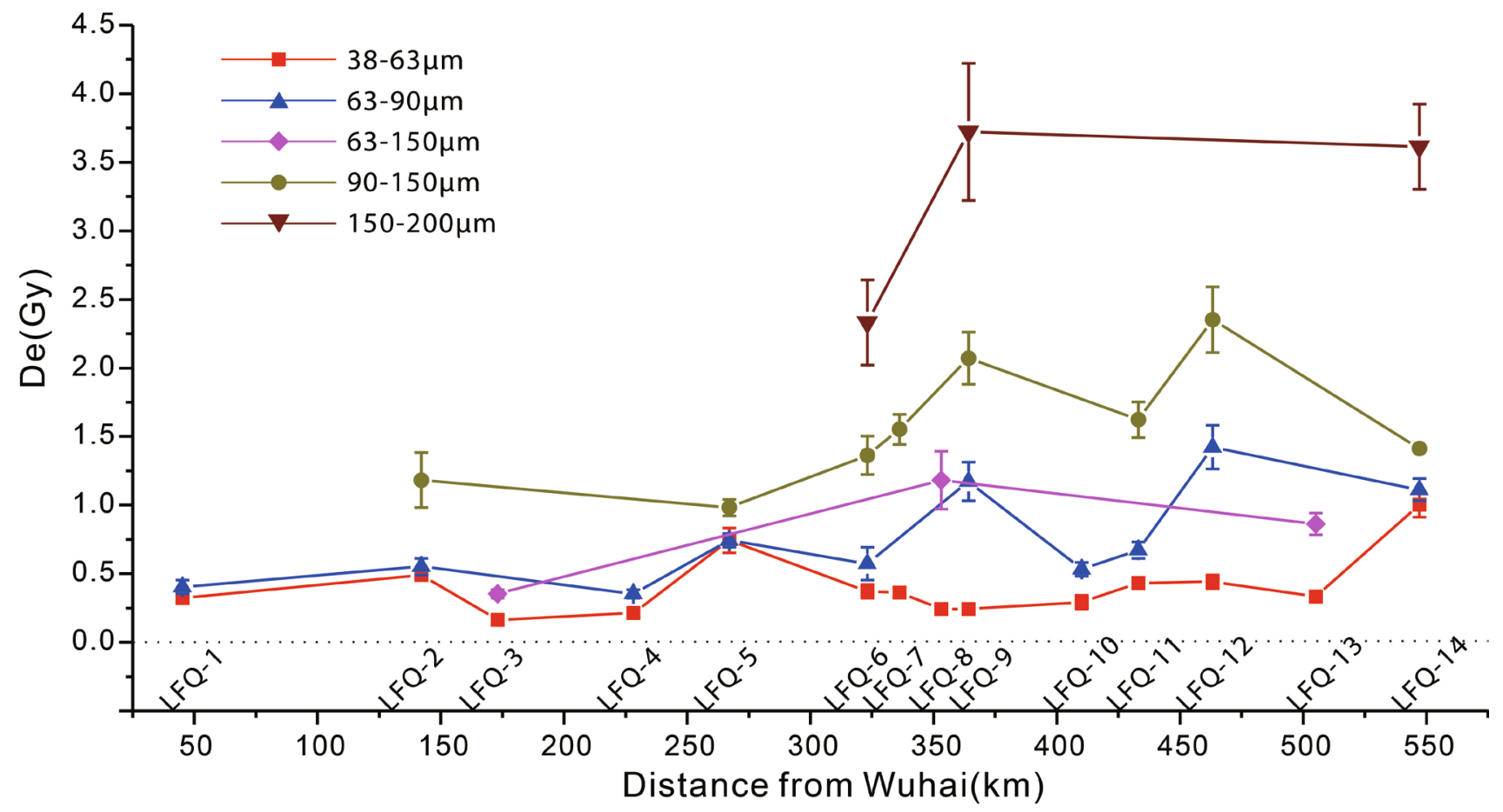

Fig. 4. $D_{\mathrm{e}}$ values of different grain sizes for modern samples versus downstream distance. 

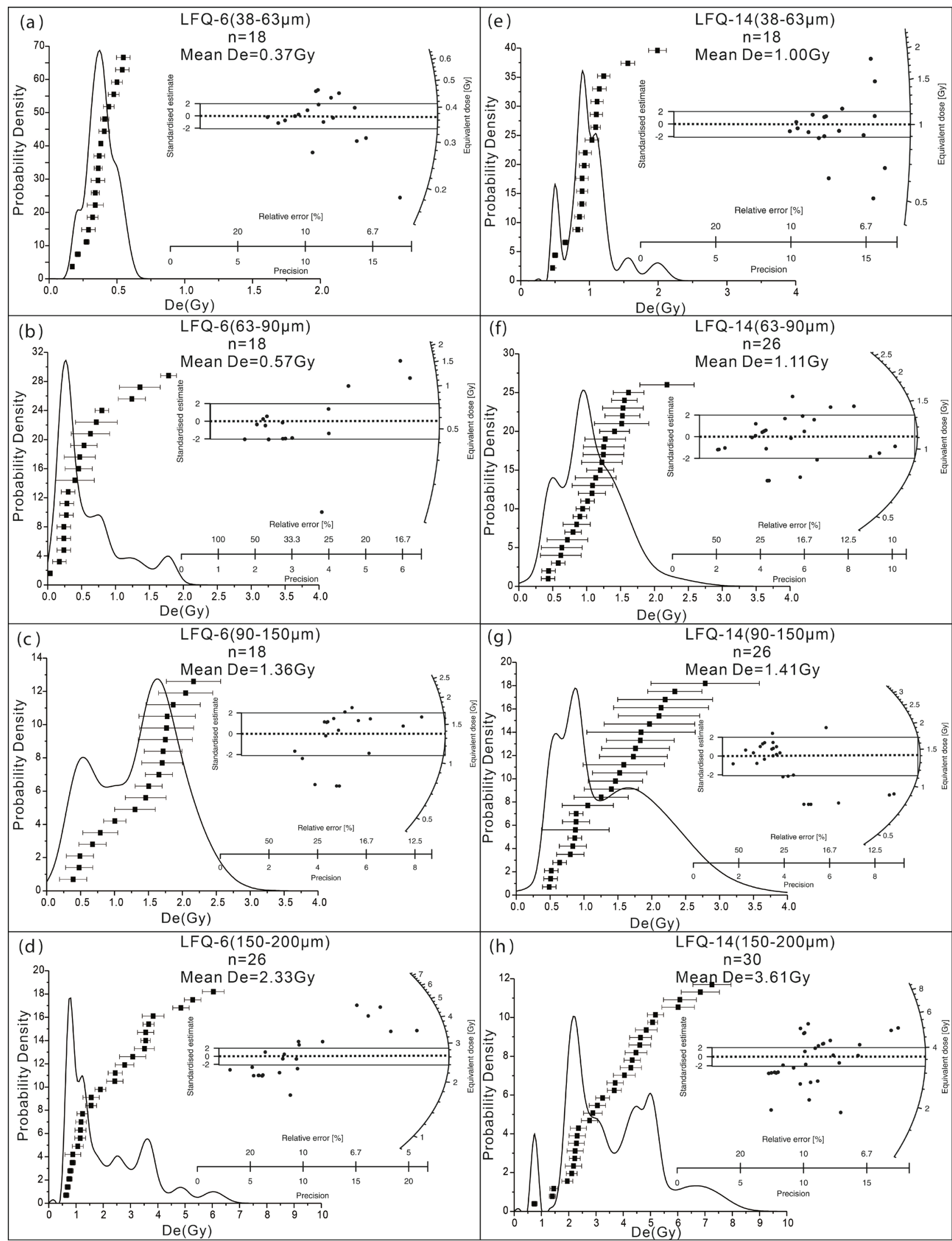

Fig. 5. Frequency distributions, probability density functions and radial plots of individual $D_{\mathrm{e}}$ values and errors for different grain sizes of $L F Q-6$ and $L F Q-14$ 
Table 1. OSL dating results for 14 modern fluvial samples.

\begin{tabular}{|c|c|c|c|c|c|c|c|c|c|}
\hline Sample ID & $\begin{array}{l}\text { Depth } \\
\text { (m) }\end{array}$ & $\begin{array}{c}\mathrm{K} \\
(\%) \\
\end{array}$ & $\begin{array}{c}\text { Th } \\
\text { (ppm) }\end{array}$ & $\begin{array}{c}U \\
\text { (ppm) }\end{array}$ & $\begin{array}{c}\text { Water content } \\
(\%)\end{array}$ & $\begin{array}{c}\text { Grain size } \\
(\mu \mathrm{m})\end{array}$ & $\begin{array}{l}\text { Dose rate } \\
\text { (Gy/ka) }\end{array}$ & $\begin{array}{l}D_{e} \\
(G y)\end{array}$ & $\begin{array}{l}\text { OSL age } \\
\text { (a) }\end{array}$ \\
\hline$\overline{L F Q-1}$ & $0.2 \pm 0.05$ & $1.80 \pm 0.06$ & $11.70 \pm 0.33$ & $2.72 \pm 0.11$ & $15 \pm 5$ & $\begin{array}{l}38-63 \\
63-90\end{array}$ & $\begin{array}{l}2.99 \pm 0.20 \\
2.97 \pm 0.20\end{array}$ & $\begin{array}{l}0.32 \pm 0.03 \\
0.40 \pm 0.05\end{array}$ & $\begin{array}{l}110 \pm 10 \\
130 \pm 20\end{array}$ \\
\hline LFQ-2 & $0.2 \pm 0.05$ & $1.69 \pm 0.06$ & $9.52 \pm 0.29$ & $2.70 \pm 0.11$ & $15 \pm 5$ & $\begin{array}{c}38-63 \\
63-90 \\
90-150 \\
\end{array}$ & $\begin{array}{l}2.77 \pm 0.19 \\
2.74 \pm 0.19 \\
2.71 \pm 0.19\end{array}$ & $\begin{array}{l}0.49 \pm 0.04 \\
0.55 \pm 0.06 \\
1.18 \pm 0.20\end{array}$ & $\begin{array}{l}180 \pm 20 \\
200 \pm 30 \\
440 \pm 80\end{array}$ \\
\hline LFQ-3 & $0.2 \pm 0.05$ & $1.64 \pm 0.05$ & $10.80 \pm 0.30$ & $2.54 \pm 0.10$ & $15 \pm 5$ & $\begin{array}{c}38-63 \\
63-150\end{array}$ & $\begin{array}{l}2.77 \pm 0.19 \\
2.72 \pm 0.18\end{array}$ & $\begin{array}{l}0.16 \pm 0.01 \\
0.35 \pm 0.03\end{array}$ & $\begin{array}{c}60 \pm 10 \\
130 \pm 10\end{array}$ \\
\hline LFQ-4 & $0.2 \pm 0.05$ & $1.81 \pm 0.06$ & $11.60 \pm 0.32$ & $3.06 \pm 0.11$ & $15 \pm 5$ & $\begin{array}{l}38-63 \\
63-90\end{array}$ & $\begin{array}{l}3.06 \pm 0.21 \\
3.00 \pm 0.20\end{array}$ & $\begin{array}{l}0.21 \pm 0.02 \\
0.35 \pm 0.03\end{array}$ & $\begin{array}{c}70 \pm 10 \\
120 \pm 10\end{array}$ \\
\hline LFQ-5 & $0.2 \pm 0.05$ & $1.87 \pm 0.06$ & $10.90 \pm 0.31$ & $2.84 \pm 0.11$ & $15 \pm 5$ & $\begin{array}{c}38-63 \\
63-90 \\
90-150\end{array}$ & $\begin{array}{l}3.03 \pm 0.20 \\
2.97 \pm 0.20 \\
2.76 \pm 0.19\end{array}$ & $\begin{array}{l}0.74 \pm 0.09 \\
0.74 \pm 0.05 \\
0.98 \pm 0.06\end{array}$ & $\begin{array}{l}240 \pm 30 \\
250 \pm 20 \\
330 \pm 30\end{array}$ \\
\hline$\overline{L F Q-6}$ & $0.2 \pm 0.05$ & $1.60 \pm 0.05$ & $10.9 \pm 0.31$ & $2.70 \pm 0.11$ & $15 \pm 5$ & $\begin{array}{c}38-63 \\
63-90 \\
90-150 \\
150-200 \\
\end{array}$ & $\begin{array}{l}2.77 \pm 0.19 \\
2.75 \pm 0.19 \\
2.72 \pm 0.19 \\
2.68 \pm 0.18\end{array}$ & $\begin{array}{l}0.37 \pm 0.05 \\
0.57 \pm 0.12 \\
1.36 \pm 0.14 \\
2.33 \pm 0.31\end{array}$ & $\begin{array}{c}130 \pm 20 \\
210 \pm 50 \\
500 \pm 60 \\
870 \pm 130\end{array}$ \\
\hline LFQ-7 & $0.2 \pm 0.05$ & $1.67 \pm 0.06$ & $10.30 \pm 0.30$ & $2.80 \pm 0.11$ & $15 \pm 5$ & $\begin{array}{c}38-63 \\
90-150\end{array}$ & $\begin{array}{l}2.82 \pm 0.19 \\
2.76 \pm 0.19\end{array}$ & $\begin{array}{l}0.36 \pm 0.03 \\
1.55 \pm 0.11\end{array}$ & $\begin{array}{l}130 \pm 10 \\
560 \pm 60\end{array}$ \\
\hline LFQ-8 & $0.2 \pm 0.05$ & $1.78 \pm 0.06$ & $10.1 \pm 0.29$ & $2.43 \pm 0.10$ & $15 \pm 5$ & $\begin{array}{c}38-63 \\
63-150\end{array}$ & $\begin{array}{l}2.82 \pm 0.19 \\
2.81 \pm 0.19\end{array}$ & $\begin{array}{l}0.24 \pm 0.02 \\
1.18 \pm 0.21\end{array}$ & $\begin{array}{c}90 \pm 10 \\
430 \pm 80\end{array}$ \\
\hline LFQ-9 & $0.2 \pm 0.05$ & $1.51 \pm 0.05$ & $13.5 \pm 0.36$ & $3.38 \pm 0.12$ & $15 \pm 5$ & $\begin{array}{c}38-63 \\
63-90 \\
90-150 \\
150-200\end{array}$ & $\begin{array}{l}2.99 \pm 0.20 \\
2.97 \pm 0.20 \\
2.94 \pm 0.19 \\
2.89 \pm 0.19\end{array}$ & $\begin{array}{l}0.24 \pm 0.01 \\
1.17 \pm 0.14 \\
2.07 \pm 0.19 \\
3.72 \pm 0.50\end{array}$ & $\begin{array}{c}80 \pm 10 \\
390 \pm 50 \\
710 \pm 80 \\
1290 \pm 190\end{array}$ \\
\hline LFQ-10 & $0.2 \pm 0.05$ & $1.66 \pm 0.05$ & $12.00 \pm 0.34$ & $3.36 \pm 0.12$ & $15 \pm 5$ & $\begin{array}{l}38-63 \\
63-90\end{array}$ & $\begin{array}{l}3.02 \pm 0.20 \\
3.00 \pm 0.20\end{array}$ & $\begin{array}{l}0.29 \pm 0.05 \\
0.53 \pm 0.05\end{array}$ & $\begin{array}{l}100 \pm 20 \\
180 \pm 20\end{array}$ \\
\hline LFQ-11 & $0.2 \pm 0.05$ & $1.65 \pm 0.05$ & $10.6 \pm 0.31$ & $2.60 \pm 0.10$ & $15 \pm 5$ & $\begin{array}{c}38-63 \\
63-90 \\
90-150\end{array}$ & $\begin{array}{l}2.78 \pm 0.19 \\
2.75 \pm 0.19 \\
2.72 \pm 0.18\end{array}$ & $\begin{array}{l}0.43 \pm 0.04 \\
0.67 \pm 0.06 \\
1.62 \pm 0.13\end{array}$ & $\begin{array}{l}150 \pm 20 \\
240 \pm 30 \\
590 \pm 60\end{array}$ \\
\hline LFQ-12 & $0.2 \pm 0.05$ & $1.75 \pm 0.06$ & $9.95 \pm 0.29$ & $2.60 \pm 0.10$ & $15 \pm 5$ & $\begin{array}{c}38-63 \\
63-90 \\
90-150 \\
\end{array}$ & $\begin{array}{l}2.82 \pm 0.19 \\
2.80 \pm 0.19 \\
2.77 \pm 0.19\end{array}$ & $\begin{array}{l}0.44 \pm 0.05 \\
1.42 \pm 0.16 \\
2.35 \pm 0.24\end{array}$ & $\begin{array}{c}160 \pm 20 \\
510 \pm 70 \\
850 \pm 100\end{array}$ \\
\hline LFQ-13 & $0.2 \pm 0.05$ & $1.76 \pm 0.06$ & $11.1 \pm 0.31$ & $2.38 \pm 0.10$ & $15 \pm 5$ & $\begin{array}{c}38-63 \\
63-150 \\
\end{array}$ & $\begin{array}{l}2.85 \pm 0.19 \\
2.81 \pm 0.19\end{array}$ & $\begin{array}{l}0.33 \pm 0.02 \\
0.86 \pm 0.08\end{array}$ & $\begin{array}{l}120 \pm 10 \\
310 \pm 40\end{array}$ \\
\hline LFQ-14 & $0.2 \pm 0.05$ & $1.63 \pm 0.05$ & $7.90 \pm 0.24$ & $1.89 \pm 0.08$ & $15 \pm 5$ & $\begin{array}{c}38-63 \\
63-90 \\
90-150 \\
150-200\end{array}$ & $\begin{array}{l}2.45 \pm 0.17 \\
2.43 \pm 0.17 \\
2.41 \pm 0.17 \\
2.37 \pm 0.19\end{array}$ & $\begin{array}{l}1.00 \pm 0.09 \\
1.11 \pm 0.08 \\
1.41 \pm 0.13 \\
3.61 \pm 0.31\end{array}$ & $\begin{array}{r}410 \pm 40 \\
460 \pm 50 \\
590 \pm 70 \\
1520 \pm 170\end{array}$ \\
\hline
\end{tabular}

\section{Core OSL and AMS ${ }^{14} \mathrm{C}$ ages}

The OSL ages of each sample, with their $D_{e}$ values and dose rate information, are given in Table 2. A total of 26 OSL dating results are displayed in Fig. 6. It is apparent that the OSL ages from all drilling cores increase with an increasing depth. The OSL ages of fluvial sediments fall within the 114 to $0.8 \mathrm{ka}$ range. The $38-63 \mu \mathrm{m}$ grain size fraction was measured; when the samples lack this fraction, we used the coarser $90-125 \mu \mathrm{m}$ fraction.

A total of $11{ }^{14} \mathrm{C}$ dates were collected from seven drilling cores. Their ${ }^{14} \mathrm{C}$ dates are listed in Table 3 and displayed in Fig. 6. All ${ }^{14} \mathrm{C}$ dates fall within the 48130 to 2160 cal BP range. The ${ }^{14} \mathrm{C}$ ages were either in agreement with the OSL ages, or fell into the same stratigraphic order as the OSL ages (Fig. 7). However, the ${ }^{14} \mathrm{C}$ ages of the three samples HDZ03-09, HDZ12-09 and DKZ06-08 were 2340-2650, 2210-2360 and 13460-13720 cal BP, i.e. much older than the OSL ages in the strata above and below. Samples HDZ03-09 and HDZ12-09 both included fragments of plant stems collected from the sand strata, at a depth of $9.1 \mathrm{~m}$ in Core HDZ03, and $3.2 \mathrm{~m}$ in Core HDZ12. If calibrated ${ }^{14} \mathrm{C}$ results were presented on the same time scale as OSL dates(ka), these samples yielded ages of $2.56 \pm 0.15$ and $2.35 \pm 0.08 \mathrm{ka}$, respectively. Sample DKZ06-08, composed of organic matter found in the clayey sediment, gave an age of $13.65 \pm 0.13 \mathrm{ka}$. 
Table 2. OSL dating results for 26 samples from seven fluvial cores.

\begin{tabular}{|c|c|c|c|c|c|c|c|c|c|}
\hline Sample ID & $\begin{array}{c}\text { Grain Size } \\
(\mu \mathrm{m})\end{array}$ & $\begin{array}{l}\text { Depth } \\
\text { (m) }\end{array}$ & $\begin{array}{c}\mathrm{K} \\
(\%)\end{array}$ & $\begin{array}{c}\text { Th } \\
\text { (ppm) }\end{array}$ & $\begin{array}{c}U \\
\text { (ppm) }\end{array}$ & $\begin{array}{c}\text { Water content } \\
(\%)\end{array}$ & $\begin{array}{c}\text { Dose rate } \\
\text { (Gy/ka) }\end{array}$ & $\begin{array}{l}D_{e} \\
(G y)\end{array}$ & $\begin{array}{l}\text { OSL age } \\
\text { (ka) }\end{array}$ \\
\hline HDZ03-06 & $38-63$ & 3.9 & $1.54 \pm 0.06$ & $9.32 \pm 0.29$ & $2.09 \pm 0.15$ & $24 \pm 5$ & $2.18 \pm 0.16$ & $2.39 \pm 0.12$ & $1.1 \pm 0.1$ \\
\hline HDZ03-14 & $38-63$ & 14.3 & $1.54 \pm 0.06$ & $4.15 \pm 0.18$ & $1.13 \pm 0.14$ & $20 \pm 5$ & $1.79 \pm 0.14$ & $2.53 \pm 0.17$ & $1.4 \pm 0.1$ \\
\hline HDZ03-17 & $38-63$ & 18.7 & $1.65 \pm 0.06$ & $4.95 \pm 0.19$ & $1.03 \pm 0.14$ & $23 \pm 5$ & $1.66 \pm 0.13$ & $58.77 \pm 1.51$ & $35.3 \pm 2.9$ \\
\hline HDZ08-11 & $38-63$ & 11.2 & $1.52 \pm 0.06$ & $5.03 \pm 0.20$ & $1.24 \pm 0.13$ & $21 \pm 5$ & $1.72 \pm 0.13$ & $8.19 \pm 0.38$ & $4.8 \pm 0.4$ \\
\hline HDZ12-03 & $38-63$ & 1.5 & $1.89 \pm 0.09$ & $11.35 \pm 0.33$ & $2.45 \pm 0.20$ & $23 \pm 5$ & $2.81 \pm 0.20$ & $2.31 \pm 0.15$ & $0.8 \pm 0.1$ \\
\hline HDZ12-07 & $38-63$ & 7.0 & $1.70 \pm 0.08$ & $5.69 \pm 0.20$ & $1.19 \pm 0.13$ & $21 \pm 5$ & $2.00 \pm 0.16$ & $2.58 \pm 0.23$ & $1.3 \pm 0.2$ \\
\hline HDZ12-09 & $38-63$ & 11.2 & $1.62 \pm 0.09$ & $4.96 \pm 0.19$ & $1.06 \pm 0.14$ & $22 \pm 5$ & $1.81 \pm 0.15$ & $2.45 \pm 0.11$ & $1.4 \pm 0.1$ \\
\hline DKZ06-07 & $38-63$ & 5.1 & $1.81 \pm 0.07$ & $6.09 \pm 0.23$ & $1.30 \pm 0.14$ & $8 \pm 5$ & $2.59 \pm 0.20$ & $19.74 \pm 0.84$ & $7.6 \pm 0.7$ \\
\hline DKZ06-10 & $90-125$ & 9.0 & $1.59 \pm 0.06$ & $3.33 \pm 0.18$ & $0.92 \pm 0.13$ & $15 \pm 5$ & $1.75 \pm 0.14$ & $16.28 \pm 1.20$ & $9.3 \pm 1.0$ \\
\hline DKZ06-12 & $90-125$ & 12.0 & $1.58 \pm 0.06$ & $3.65 \pm 0.17$ & $0.79 \pm 0.13$ & $13 \pm 5$ & $1.75 \pm 0.14$ & $19.74 \pm 1.05$ & $11.3 \pm 1.1$ \\
\hline DKZ06-15 & $38-63$ & 15.7 & $1.51 \pm 0.06$ & $5.00 \pm 0.20$ & $1.09 \pm 0.13$ & $19 \pm 5$ & $1.83 \pm 0.14$ & $41.91 \pm 1.30$ & $23.0 \pm 1.9$ \\
\hline DKZ06-16 & $90-125$ & 18.0 & $1.62 \pm 0.06$ & $3.72 \pm 0.19$ & $0.92 \pm 0.14$ & $18 \pm 5$ & $1.68 \pm 0.13$ & $48.71 \pm 2.46$ & $29.0 \pm 2.7$ \\
\hline DKZ09-08 & $90-125$ & 2.6 & $1.65 \pm 0.06$ & $2.59 \pm 0.16$ & $0.68 \pm 0.12$ & $9 \pm 5$ & $1.94 \pm 0.15$ & $15.52 \pm 0.81$ & $8.0 \pm 0.8$ \\
\hline DKZ09-11 & $90-125$ & 9.0 & $1.52 \pm 0.06$ & $2.60 \pm 0.15$ & $0.63 \pm 0.11$ & $14 \pm 5$ & $1.61 \pm 0.13$ & $49.61 \pm 2.09$ & $30.7 \pm 2.7$ \\
\hline DKZ09-16 & $38-63$ & 12.0 & $1.36 \pm 0.05$ & $2.95 \pm 0.17$ & $0.63 \pm 0.11$ & $15 \pm 5$ & $1.53 \pm 0.12$ & $55.30 \pm 1.36$ & $36.0 \pm 3.1$ \\
\hline DKZ09-18 & $90-125$ & 17.0 & $1.44 \pm 0.06$ & $3.10 \pm 0.17$ & $0.74 \pm 0.11$ & $18 \pm 5$ & $1.48 \pm 0.12$ & $77.01 \pm 1.92$ & $52.2 \pm 4.3$ \\
\hline DKZ09-21 & $90-125$ & 20.0 & $1.46 \pm 0.06$ & $2.53 \pm 0.14$ & $0.70 \pm 0.10$ & $15 \pm 5$ & $1.51 \pm 0.12$ & $86.44 \pm 3.89$ & $57.4 \pm 5.3$ \\
\hline DKZ10-08 & $90-125$ & 4.1 & $1.71 \pm 0.06$ & $3.29 \pm 0.19$ & $1.06 \pm 0.16$ & $12 \pm 5$ & $2.00 \pm 0.15$ & $23.68 \pm 1.18$ & $11.8 \pm 1.1$ \\
\hline DKZ10-16 & $90-125$ & 9.7 & $1.52 \pm 0.06$ & $3.22 \pm 0.19$ & $0.76 \pm 0.12$ & $16 \pm 5$ & $1.62 \pm 0.13$ & $25.76 \pm 1.03$ & $15.9 \pm 1.4$ \\
\hline DKZ10-20 & $90-125$ & 13.2 & $1.75 \pm 0.06$ & $4.49 \pm 0.21$ & $1.20 \pm 0.15$ & $16 \pm 5$ & $1.95 \pm 0.15$ & $156.25 \pm 5.79$ & $80.2 \pm 6.8$ \\
\hline DKZ10-23 & $38-63$ & 19.5 & $1.76 \pm 0.07$ & $4.58 \pm 0.21$ & $0.97 \pm 0.12$ & $16 \pm 5$ & $1.93 \pm 0.15$ & $197.41 \pm 8.21$ & $102.1 \pm 9.0$ \\
\hline DKZ13-06 & $38-63$ & 3.2 & $1.77 \pm 0.08$ & $5.64 \pm 0.19$ & $1.27 \pm 0.13$ & $22 \pm 5$ & $2.02 \pm 0.15$ & $3.10 \pm 0.60$ & $1.5 \pm 0.3$ \\
\hline DKZ13-08 & $38-63$ & 5.2 & $1.44 \pm 0.07$ & $4.24 \pm 0.17$ & $0.86 \pm 0.12$ & $20 \pm 5$ & $1.62 \pm 0.12$ & $4.47 \pm 0.35$ & $2.8 \pm 0.3$ \\
\hline DKZ13-16 & $38-63$ & 11.9 & $1.76 \pm 0.08$ & $10.88 \pm 0.32$ & $3.18 \pm 0.22$ & $17 \pm 5$ & $2.74 \pm 0.20$ & \multicolumn{2}{|c|}{$276.16 \pm 12.15100 .8 \pm 8.5$} \\
\hline DKZ13-19 & $38-63$ & 15.1 & $1.83 \pm 0.08$ & $7.64 \pm 0.24$ & $2.14 \pm 0.16$ & $20 \pm 5$ & $2.29 \pm 0.17$ & \multicolumn{2}{|c|}{$261.27 \pm 11.52114 .1 \pm 9.9$} \\
\hline
\end{tabular}

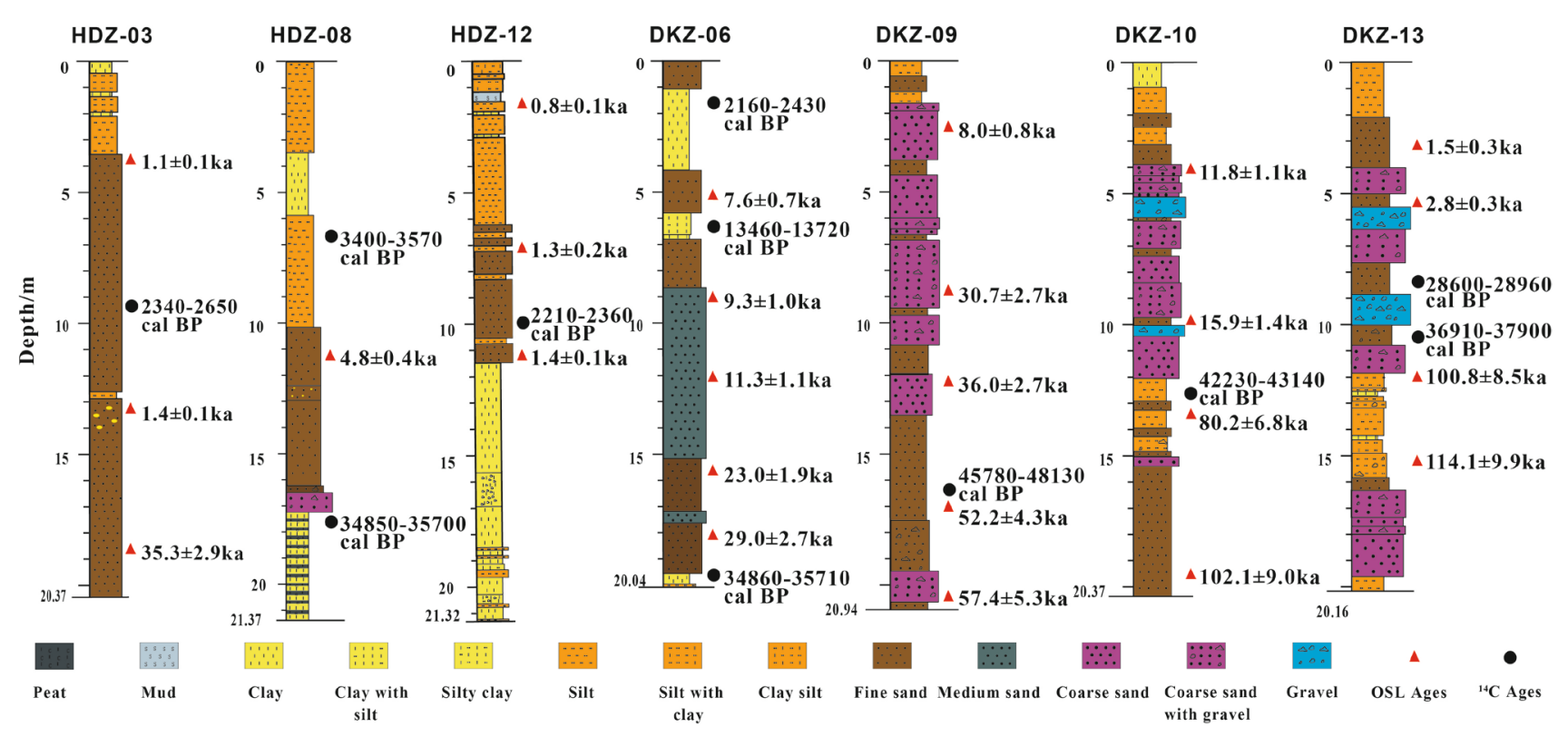

Fig. 6. Relation between calibrated ${ }^{14} \mathrm{C}$ and OSL ages, and depth. 
F.Q. Li et al.

Table 3. Sample data and ${ }^{14} \mathrm{C}$ age results for 11 samples from seven fluvial cores.

\begin{tabular}{llccccc}
\hline Sample ID & Lab Code & $\begin{array}{c}\text { Depth } \\
(\mathbf{m})\end{array}$ & Material & $\begin{array}{c}\delta{ }^{13} \mathbf{C} \\
(\%)\end{array}$ & $\begin{array}{c}{ }^{14} \mathbf{C} \text { age } \\
\text { (BP) }\end{array}$ & $\begin{array}{c}\text { Calibrated age } \\
95.4 \% \text { confidence interval } \\
(\mathbf{c a l ~ B P})\end{array}$ \\
\hline HDZ03-09 & LZU1424 & 9.1 & plant residue & -36.4 & $2375 \pm 30$ & $2340-2650$ \\
\hline HDZ08-09 & Beta-385805 & 6.5 & clay & -23.1 & $3260 \pm 30$ & $3400-3570$ \\
\hline HDZ08-14 & Beta-385806 & 17.6 & clay & -25.7 & $31400 \pm 170$ & $34850-35700$ \\
\hline HDZ12-09 & LZU1316 & 3.2 & plant residue & -35.6 & $2315 \pm 25$ & $2210-2360$ \\
\hline DKZ06-02 & Beta-385798 & 1.5 & clay & -22.5 & $2310 \pm 40$ & $2160-2430$ \\
\hline DKZ06-08 & Beta-385799 & 5.8 & clay & -23.3 & $11740 \pm 50$ & $13460-13720$ \\
\hline DKZ06-17 & Beta-385800 & 19.5 & clay & -23.6 & $31410 \pm 170$ & $34860-35710$ \\
\hline DKZ09-18 & LZU1422 & 16.7 & plant residue & -33.0 & $43680 \pm 520$ & $45780-48130$ \\
\hline DKZ10-20 & LZU1426 & 13 & plant residue & -37.2 & $38730 \pm 320$ & $42230-43140$ \\
\hline DKZ13-11 & Beta-385802 & 8.1 & clay & -23.4 & $24770 \pm 30$ & $28600-28960$ \\
\hline DKZ13-12 & LZU1425 & 9.7 & clay & -26.3 & $33210 \pm 30$ & $36910-37900$ \\
\hline
\end{tabular}

\section{DISCUSSION}

\section{Modern samples}

\section{The bleaching of OSL signals}

A typical natural OSL decay curve for modern fluvial sediment shows that the OSL natural signal is very low (Fig. 3a). The comparison of the distribution pattern in Fig. 5 shows that the $D_{e}$ values of the different quartz fractions have small residuals. We extracted modern samples from a depth of 15 to $20 \mathrm{~cm}$ below the surface, which might be the reason for the small residuals. If an average deposition rate of $0.12 \mathrm{~cm} / \mathrm{a}$ for the river channel in the Inner Mongolian reaches of the Yellow River (Pan et al., 2015) is used, the ages are about 120-170 a, which are smaller than, or equal to, the measured ages $(60$ 410 a) of medium-grained quartz fractions, and most of the medium quartz grains can be considered to have been relatively well bleached prior to deposition. In all of our modern samples, the residual dose for the medium and coarse-grained quartz fractions $(38-63,63-90,63-150$, $90-150 \mu \mathrm{m})$ ranged from 0.16 to $2.35 \mathrm{~Gy}$, correspondingly, with the ages ranging from 60 a to 850 a (Table 1; Fig. 4). They are smaller than, or equal to, the residual doses of quartz grains from the modern fluvial sediments obtained from other rivers in the world (Jain et al., 2004; Fuchs et al., 2005; Singarayer et al., 2005; Vandenberghe et al., 2007; Alexanderson, 2007; Alexanderson and Murray, 2012). Hu et al. (2010) obtained the $\mathrm{D}_{\mathrm{e}}$ distributions for coarse-grained $(180-250 \mu \mathrm{m})$ quartz fraction from the sand-sized samples derived from the middle reaches of the Yellow River between Hekouzhen and Longmen. The $\mathrm{D}_{\mathrm{e}}$ values of these samples ranged from 1.6 to $6.4 \mathrm{~Gy}$, peaking at $56 \mathrm{~Gy}$. This indicates that the OSL signals in some grains were not completely bleached prior to burial, although most of the quartz grains can be considered to have been relatively well bleached prior to deposition. Fuchs et al. (2005) compared residual luminescence signals between the quartz and feldspar of fine- and coarsegrained fractions of the recent river flood sediments from the River Elbe in Saxony, Germany. Their residual $D_{e}$ values ranged from 0.5 Gy to 2.32 Gy for fine- and coarse-grained quartz; the distinctly lower $\mathrm{D}_{\mathrm{e}}$ values for quartz indicated thorough bleaching prior to deposition. Two samples collected from a recent alluvial deposit in the River Chavanne (in southern Belgium) (Vandenberghe et al., 2007) showed residual $\mathrm{D}_{\mathrm{e}}$ values (obtained using large aliquots of quartz) ranging from $0.3 \mathrm{~Gy}$ to 0.6 Gy. These findings suggest that it might be possible to extract the true burial dose and age from such samples. They also indicate thorough bleaching prior to deposition. Compared with the residual doses of modern fluvial sediments from the other rivers in the world, the small residual dose (0.16-2.35 Gy) for the medium and coarsegrained quartz fractions $(38-63,63-90,63-150,90$ $150 \mu \mathrm{m}$ ) obtained from modern fluvial sediments along the Inner Mongolian reaches of the Yellow River implies that they were well bleached prior to deposition.

Assuming that the modern (recently deposited) samples and core samples experienced the same depositional conditions, we could use these modern analogues to assess the degree of bleaching in older core samples (e.g. Gliganic et al., 2017). We therefore subtracted the calculated residual dose from the $\mathrm{D}_{\mathrm{e}} \mathrm{s}$ of modern samples for all older core samples. Jain et al. (2004) considered that residual OSL signals can be relatively unimportant for fluvial samples $>1$ ka old. However, $\mathrm{Hu}$ et al. (2010) showed that, for young fluvial samples from the middle reaches of the Yellow River, even for some samples $>1 \mathrm{ka}$ in age, the influence of the residual OSL signal on the dating result in some grains cannot be assumed to be negligible. According to the $\mathrm{D}_{\mathrm{e}}$ values extracted from drilling core samples from the Inner Mongolian reaches of the Yellow River (Table 2; Fig. 6), the minimum $D_{e}$ values for the medium-grained $(38-63 \mu \mathrm{m})$ fraction were $2.31 \pm 0.15 \mathrm{~Gy}$, corresponding to the age of $0.8 \pm 0.1 \mathrm{ka}$, whereas for the coarse-grained $(90-125 \mu \mathrm{m})$ fraction these amounted to $15.52 \pm 0.81 \mathrm{~Gy}$, corresponding to the age of $8.0 \pm 0.8 \mathrm{ka}$, i.e. almost all the ages of drilling core samples are older than $1 \mathrm{ka}$. The residual OSL signals for 
the medium-grained $(38-63 \mu \mathrm{m})$ quartz fraction from modern samples range principally between 0.16 and $0.49 \mathrm{~Gy}$, with the ages between 60 a and 180 a. Notably, the influence of the residual signals in some grains on the dating results of drilling core samples $(\sim 1 \mathrm{ka})$ can be assumed to be unlikely to lead to significant age overestimations for older sediments, implying that they exerted almost no influence on the samples from drilling cores. However, the maximum $D_{e}$ of the 38-63 $\mu \mathrm{m}$ fraction value obtained is up to 1 Gy (LFQ-14), and the age is $410 \pm 40$ a, implying that this might have a significant effect on the core samples younger than $\sim 1 \mathrm{ka}$, butlittle influence on older core samples.

\section{A comparison of $D_{e}$ values for different grain sizes}

The rate and completeness of bleaching is dependent on a number of variables in fluvial environments (Jain et al., 2004). The differently-sized sediments found in rivers can originate from different sources, and from the fact that they were variously transported over differing distances, and they can therefore be safely assumed to have different bleaching histories (Stokes et al., 2001; Jain et al., 2004; Rittenour, 2008). These variables might thus yield new and valuable information when reconstructing the processes and patterns of sedimentary transport and deposition in the past (Cunningham et al., 2015).

This study shows that medium-grained quartz seems to be better bleached than coarse-grained quartz. Coarser grains $(150-200 \mu \mathrm{m})$ have significantly larger doses than medium and coarse grains. For most of the modern samples, there is also a slight increase in $D_{e}$ with an increasing grain size (Fig. 4). This is contrary to the results from previous investigations of different grain-size fractions of fluvial sediments (e.g. Alexanderson, 2007; Rittenour, 2008; Hu et al., 2010). In those studies, the coarser grain sizes had lower $D_{e}$ values and were generally better bleached on deposition. The reasons for the difference in bleaching between finer and coarser grain sizes in this study are not fully understood, and they are probably related to the mode of transport (Rittenour, 2008) and sources (Hu et al., 2010).

The Inner Mongolian reaches of the Yellow River represent a typical alluvial channel in terms of the highly complex alternation between runoff and sedimentation, as well as the high-frequency evolution of the river channel (Ta et al., 2003). The upper reaches of this stretch of the Yellow River flow through a desert, and so bank erosion and accretion occur frequently in this area. The sedimentary source is complex, including materials carried from upstream, aeolian sand carried by sandstorms, processes of river lateral erosion, materials derived from bank erosion and collapse, as well as materials from ten tributaries (Yang, 2002; Ta et al., 2003; Ran and Wang, 2010). Therefore, sedimentary grain sizes possibly possess the previously accumulated doses of varying magnitude, originating from different sources, and have different transportation histories or sedimentation processes. According to Ta et al. (2011) and Pan et al. (2015), most fine sediments $(<80 \mu \mathrm{m})$ enter the Inner Mongolian reaches of the Yellow River from upstream and its tributaries through suspended loads, whereas most coarse sediment $(>80 \mu \mathrm{m})$ inputs from the local desert regions are wind-blown, or result from tributary confluences and sandy bank failures through bedload. The possible explanation is that fine sediment $(<80 \mu \mathrm{m})$ would be better bleached due to these sediments' being transported in suspension in the water column and exposed to solar light for a longer time, and due to them being stronger than coarser bed-load grains during such long transport (Murray, 1996). Coarse sediment $(>80 \mu \mathrm{m})$ is more likely to have been transported as bedload by saltation or tractive forces at the base of the water column, as the high turbidity of water limits light penetration (Rittenour, 2008). Besides, although coarse sediments contain some wellbleached grains from the sand dune material due to windblowing, the grains have previously accumulated doses from tributary confluences, sandy bank failures and lateral dunes eroded by the river, are common.

As shown in Fig. 4, the $D_{e}$ values for the coarsergrained fractions $(150-200 \mu \mathrm{m})$ from LFQ-6, LFQ-9 and LFQ-14 are 2.33, 3.72 and $3.61 \mathrm{~Gy}$, respectively, and the individual $\mathrm{D}_{\mathrm{e}}$ value reaches up to $7.5 \mathrm{~Gy}$ (Fig. 5h), which is greater than, or equal to, those of medium and coarse quartz grains $(<150 \mu \mathrm{m})$. The scattered $\mathrm{D}_{\mathrm{e}}$ distributions for the coarser-grained fractions (150-200 $\mu \mathrm{m})$ may indicate that the coarser grains were both poorly and heterogeneously bleached prior to deposition, and might be better explained by a mixture of a small number of poorly-bleached grains and a larger number of well-bleached grains (Olley et al., 1998, 1999). Anyway, we have assumed that medium-grained quartz is preferable to coarse-grained quartz when dating fluvial sand samples based on the different grain sizes from different sources (previously accumulated doses of varying magnitude) and different sedimentation processes.

\section{Bleaching and transport distance}

In our study, the $\mathrm{D}_{\mathrm{e}}$ values of medium-grained (38$63 \mu \mathrm{m})$ quartz fraction from all the modern fluvial samples exhibited no decrease with an increasing transport distance (Fig. 4). Sedimentary inputs from riverbank erosion or tributaries may as well change this pattern. Shields (1936) used critical shear stress and critical mean flow velocity curves to predict the critical conditions for initial sedimentary movement. This defines the critical bed shear stress necessary to set particles of a given size in motion. For clay $(0-3.9 \mu \mathrm{m})$ and silt $(3.9-63 \mu \mathrm{m})$ particles to erode and then remain in suspension, they require higher shear stresses and flow velocity. Once set in motion within the fluvial environment, they can be transported over considerable distances. When the velocity of flow falls below the settling velocity, they are then deposited, and can only be re-eroded with difficulty (Miller et 
al., 1977). Besides, the finer fluvial sediments $(<80 \mu \mathrm{m})$ are deposited from a distant source (mainly from the upper reaches and Ten tributaries) (Ta et al., 2011; Pan et al., 2015). This indicates that medium-grained (38-63 $\mu \mathrm{m})$ quartz fraction may have been transported over a considerable distance from its source, during which it might have been exposed to sunlight for extended periods of time (Stokes et al., 2001).

By contrast to the medium-grained $(38-63 \mu \mathrm{m})$ quartz fraction, the $D_{e}$ values of coarse-grained fractions (63-90, 90-150 $\mu \mathrm{m}$ ) show a stronger correlation with the distance downstream, which is readily explained by the more complex interactions with the adjacent dune sediments, tributary confluences and sandy bank failures, occurring along the length of the channel network. As discussed above, most coarse sediment $(>80 \mu \mathrm{m})$ inputs from the local desert regions are wind-blown, or result from bank erosion, tributary confluences and sandy bank failures through bedloads. It is most likely that the bedload sediments from the desert reaches to the tributary sections were not efficiently transported further downstream, and the coarse particles in the tributary reaches come mainly from the ten tributaries (Pan et al., 2015). Residual $\mathrm{D}_{\mathrm{e}}$ values normally decrease with distance downstream (Stokes et al., 2001). However, in the Inner Mongolian reaches of the Yellow River, the tributaries change the pattern of $D_{e}$ values of coarse-grained fractions with distance. Moreover, bleaching does not improve with transport distance.

\section{A comparison of OSL and ${ }^{14} \mathrm{C}$ ages for the drilling cores}

Accurate and precise dating is essential for correlating fluvial sedimentation with external forcing (Cunningham and Wallinga, 2012). Laboratory tests of luminescence and OSL age characteristics were used to assess the precision of particular dating methods, but could not test the accuracy of the ages found (Zhang et al., 2014). Numerous studies have compared OSL dating with ${ }^{14} \mathrm{C}$ dating, due to the wide application and acceptance of ${ }^{14} \mathrm{C}$ in the Quaternary research community. A clear and close correlation has often been established (Wallinga, 2002; Jain et al., 2004; Olley et al., 2004). Through the use of complementary dating techniques, we obtained a detailed chronology for the floodplain sediments of the Hetao Plain.

The OSL ages were compared with the ${ }^{14} \mathrm{C}$ ages on the stratigraphic columns for the seven cores (Figs. 6 and 7). The ${ }^{14} \mathrm{C}$ ages were either in agreement with the OSL ages, or fell into the same stratigraphic order as the OSL ages, except for the ${ }^{14} \mathrm{C}$ ages of the three samples HDZ03-09, HDZ12-09 and DKZ06-08, much older than the OSL ages in the strata above and below. If incomplete bleaching was a common problem, for the OSL-dated samples, incomplete zeroing would result in an overestimation of age, thus resulting in older OSL ages than ${ }^{14} \mathrm{C}$ ages. Sediments are known to be repeatedly exchanged through frequent river channel migration and riverbank erosion in floodplains (Dunne et al., 1998); plant stem fragments and clayey organic matter might therefore well have been reworked from older strata and incorporated into the younger sedimentary strata of these three cores. In conclusion, a comparison of the remaining OSL and ${ }^{14} \mathrm{C}$ ages, and the ${ }^{14} \mathrm{C}$ and quartz OSL ages, shows that they are in close agreement. The OSL ages are in the correct stratigraphical order. A comparison of the OSL ages with the ${ }^{14} \mathrm{C}$ ages allowed us to assume that they could reasonably be taken as representative of these cores.

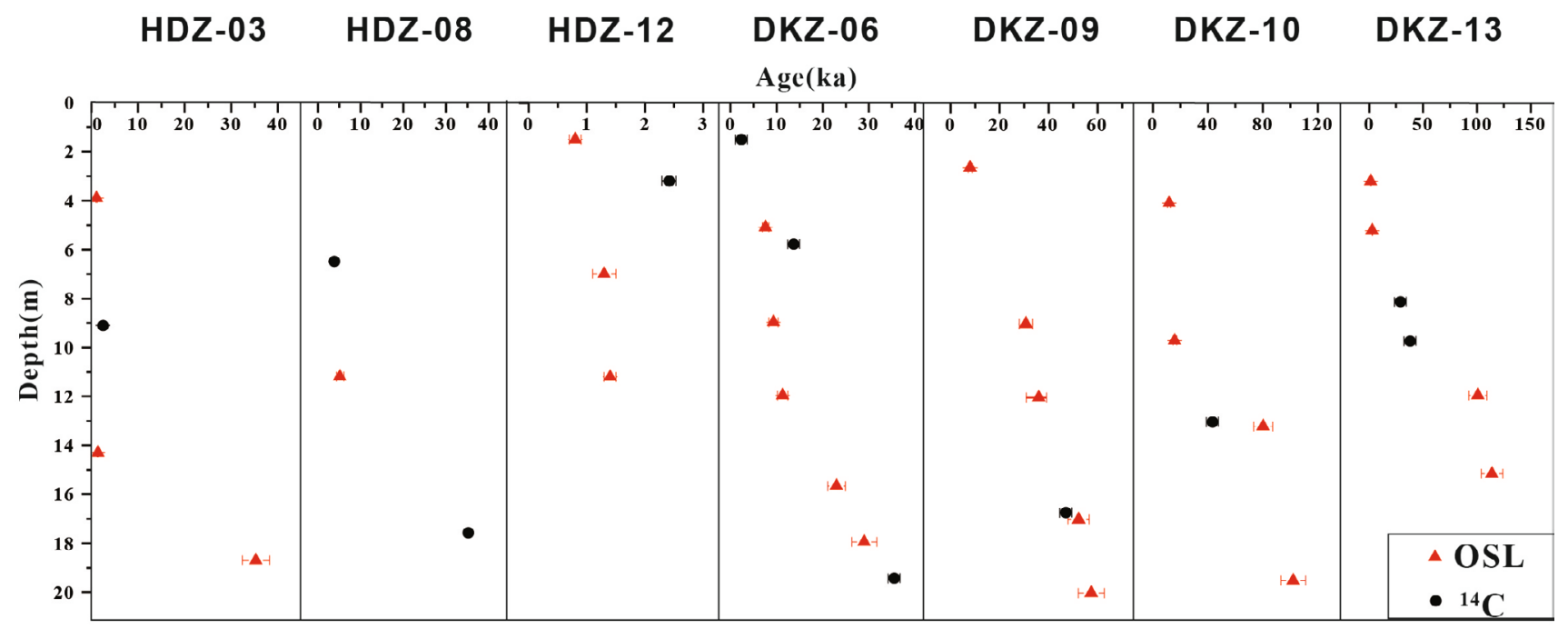

Fig. 7. The correlation between the recalibration ${ }^{14} \mathrm{C}$ (the results were presented on the same time scale as OSL dates) and the OSL ages, and depth, in drilling cores. 


\section{CONCLUSIONS}

The residual $D_{e}$ values of modern fluvial samples from the Inner Mongolian sections on the upper reaches of the Yellow River range principally between 0.16 and 0.49 Gy for silt grains $(38-63 \mu \mathrm{m})$, and between 0.35 and 3.72 Gy for sand grains of the modern fluvial sediment samples. The small residual dose for modern samples, and their luminescence signal characteristics, indicate that fluvial sediments have been relatively well bleached during transport, when compared to the residual doses of modern fluvial sediments from the middle reaches of the Yellow River and from other rivers around the world. Medium-grained quartz fractions are better bleached and more suitable than coarse-grained quartz when dating fluvial sand samples, and the $D_{e}$ values of coarse-grained $(63-90,90-150 \mu \mathrm{m})$ fractions show a stronger correlation with distance downstream, suggesting that the tributaries change the pattern of $D_{e}$ values of coarse-grained fractions with distance. In addition, a total of $11{ }^{14} \mathrm{C}$ ages were compared with 26 OSL results for drilling cores, to give confidence that the initial bleaching of these sediments was sufficient. We would therefore propose that these fluvial samples were well bleached prior to deposition, and that the OSL ages we obtained can reasonably be taken as the best estimates for the dates of initial sedimentary deposition.

\section{ACKNOWLEDGEMENTS}

We are grateful to Lianke Zhang, Xiaopeng Liu, Zongmeng Li, and Hongli Pang for their fieldwork assistance. Yixuan Wang and Xiaoyun Yang are acknowledged for their work on OSL dating measurements. This study is financially supported by the National Basic Research Programme of China (No. 2011CB403301), the National Natural Science Foundation of China (Grants Nos. 41571003 and 41471008) and the Fundamental Research Funds for the Central Universities (Grant No. LZUJBKY-2016-161).

\section{REFERENCES}

Aitken MJ, 1998. An Introduction to Optical Dating. Oxford University Press: Oxford

Alexanderson H, 2007. Residual OSL signals from modern Greenlandic river sediments. Geochronometria 26: 1-9, DOI 10.2478/v10003007-0001-6.

Alexanderson $\mathrm{H}$ and Murray AS, 2012. Luminescence signals from modern sediments in a glaciated bay, NW Svalbard. Quaternary Geochronology 10: 250-256, DOI 10.1016/j.quageo.2012.01.001.

Blong RJ and Gillespie R, 1978. Fluvially transported charcoal gives erroneous ${ }^{14} \mathrm{C}$ ages for recent deposits. Nature 271: 739-741, DOI 10.1038/271739a0.

Chen F, Fan Y, Madsen DB, Chun X, Zhao H and Yang L 2008. Preliminary study on the formation mechanism of the "JilantaiHetao" megalake and the lake evolutionary history in Hetao region. Quaternary Sciences 28: 866-873 (in Chinese with English abstract).
Colls AE, Stokes S, Blum MD and Straffin E, 2001. Age limits on the Late Quaternary evolution of the upper Loire River. Quaternary Science Reviews 20(5): 743-750, DOI 10.1016/S02773791(00)00048-2.

Cunningham AC and Wallinga J, 2012. Realizing the potential of fluvial archives using robust OSL chronologies. Quaternary Geochronology 12: 98-106, DOI 10.1016/j.quageo.2012.05.007.

Cunningham AC, Evans M and Knight J, 2015. Quantifying bleaching for zero-age fluvial sediment: a Bayesian approach. Radiation Measurements 81: 55-61, DOI 10.1016/j.radmeas.2015.04.007.

DeLong SB and Arnold LJ, 2007. Dating alluvial deposits with optically stimulated luminescence, AMS ${ }^{14} \mathrm{C}$ and cosmogenic techniques, western Transverse Ranges, California, USA. Quaternary Geochronology 2: 129-136, DOI 10.1016/j.quageo.2006.03.012.

Ditlefsen C, 1992. Bleaching of K-feldspars in turbid water suspensions: a comparison of photo-and thermoluminescence signals. Quaternary Science Reviews 11: 33-38, DOI 10.1016/02773791(92)90039-B.

Duller GAT, 2008. Single-grain optical dating of Quaternary sediments: why aliquot size matters in luminescence dating. Boreas $37(4)$ : 589-612, DOI 10.1111/j.1502-3885.2008.00051.x.

Dunne T, Mertes LAK, Meade RH, Richey JE and Forsberg BR, 1998. Exchanges of sediment between the floodplain and channel of the Amazon River in Brazil. Geological Society of America Bulletin 110(4): $\quad 450-467, \quad$ DOI $\quad 10.1130 / 0016$ 7606(1998) $110<0450$ :EOSBTF $>2.3 . C O ; 2$.

Feng $\mathrm{G}$ and Zhang Q, 2008. Integrated management of ten major streams and floods safely passing through Inner Mongolia section of the Yellow River. Soil Water Conserv China 4: 8-10 (in Chinese).

Fuchs M, Straub J and Zoller L, 2005. Residual luminescence signals of recent river flood sediments: a comparison between quartz and feldspar of fine-and coarse-grain sediments. Ancient TL 23(1): $25-30$.

Gliganic LA, Cohen TJ, Meyer M and Molenaar A, 2017. Variations in luminescence properties of quartz and feldspar from modern fluvial sediments in three rivers. Quaternary Geochronology 41: 7082, DOI 10.1016/j.quageo.2017.06.005.

Hou S, 1996. Fluvial process of the Inner Mongolian Reach of the Yellow River 1987-1993. Yellow River 9: 43-45 (in Chinese with English abstract).

Hu G, Zhang J, Qiu W and Zhou L, 2010. Residual OSL signals in modern fluvial sediments from the Yellow River (HuangHe) and the implications for dating young sediments. Quaternary Geochronology 5: 187-193, DOI 10.1016/j.quageo.2009.05.003.

Jain M, Murray AS and Botter-Jensen L, 2004. Optically stimulated luminescence dating: How significant is incomplete light exposure in fluvial environments? Quaternaire 15(1): 143-157, DOI 10.3406/quate. 2004.1762 .

Lai Z, 2006. Testing the use of an OSL standardised growth curve (SGC) for De determination on quartz from the Chinese Loess Plateau. Radiation Measurements 41(1): 9-16, DOI 10.1016/j.radmeas.2005.06.031.

Lai $\mathrm{Z}$ and Wintle AG, 2006. Locating the boundary between the Pleistocene and the Holocene in Chinese loess using luminescence. The Holocene 16(6): 893-899, DOI 10.1191/0959683606hol980rr.

Lai Z, Wintle AG and Thomas DSG, 2007a. Rates of dust deposition between $50 \mathrm{ka}$ and $20 \mathrm{ka}$ revealed by OSL dating at Yuanbao on the Chinese Loess Plateau. Palaeogeography, Palaeoclimatology, Palaeoecology 248: 431-439, DOI 10.1016/j.palaeo.2006.12.013.

Lai Z, Brückner H, Zöller L and Fülling A, 2007b. Existence of a common growth curve for silt-sized quartz OSL of loess from different continents. Radiation Measurements 42(9): 1432-1440, DOI 10.1016/j.radmeas.2007.08.006.

Lai Z and Brückner H, 2008. Effects of feldspar contamination on equivalent dose and the shape of growth curve for OSL of siltsized quartz extracted from Chinese loess. Geochronometria 30: 49-53, DOI 10.2478/v10003-008-0010-0.

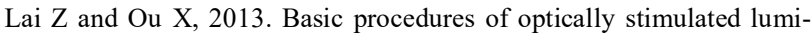
nescence (OSL) dating. Progress in Geography 32(5): 683-693 (in Chinese with English abstract), DOI 10.11820/dlkxjz.2013.05.001. 
Li B, Ge Q and Zheng J, 2003. Evolution of the Yellow River in the Houtao Plain of Inner Mongolia in the past 2000 years. Acta Geographica Sinica 2: 239-246 (in Chinese).

Li S, 2001. Identification of well-bleached grains in the optical dating of quartz. Quaternary Science Review 20(12): 1365-1370, DOI 10.1016/S0277-3791(00)00156-6.

Liu L, Li Q and Li H, 2012. Origin analysis and Management measures of "Hanging River" in the Inner Mongolia section of the Yellow River. Inner Mongolia Water Resources 2: 106-107 (in Chinese).

Liu X, Lai Z, Madsen D, Yu L, Liu K and Zhang J, 2011. Lake level variations of Qinghai Lake in northeastern Qinghai-Tibetan Plateau since $3.7 \mathrm{ka}$ based on OSL dating. Quaternary International 236: 57-64, DOI 10.1016/j.quaint.2010.08.009.

Markey BG, Bøtter-Jensen L and Duller GAT, 1997. A new flexible system for measuring thermally and optically stimulated luminescence. Radiation Measurements 27(2): 83-89, DOI 10.1016/S1350-4487(96)00126-6.

Miller MC, McCave IN and Komar PD, 1977. Threshold of sediment motion under uinidirectional currents. Sedimentology 24(4): $507-$ 527, DOI 10.1111/j.1365-3091.1977.tb00136.x.

Milliman JD and Meade RH, 1983. World-wide delivery of river sediment to the oceans. Journal of Geology 91(1): 1-21, DOI $10.1086 / 628741$

Murray AS, 1996. Developments in optically stimulated luminescence and phototransferred thermoluminescence dating of young sediments: application to a 2000-year sequence of flood deposits. Geochimica et Cosmochimica Acta 60: 565-576, DOI 10.1016/00167037(95)00418-1.

Murray AS and Wintle AG, 2000. Luminescence dating of quartz using an improved single-aliquot regenerative-dose protocol. Radiation Measurements 32(1): 57-73, DOI 10.1016/S1350-4487(99)00253$\mathrm{X}$.

Murray AS and Olley JM, 2002. Precision and accuracy in the optically stimulated luminescence dating of sedimentary quartz: A status review. Geochronometria 21: 1-16.

Olley JM, Caitcheon GG and Murray AS, 1998. The distribution of apparent dose as determined by optically stimulated luminescence in small aliquots of fluvial quartz: implications for dating young sediments. Quaternary Science Reviews 17: 1033-1040, DOI 10.1016/S0277-3791(97)00090-5.

Olley JM, Caitcheon GG and Roberts RG, 1999. The origin of dose distributions in fluvial sediments, and the prospect of dating single grains from fluvial deposits using optically stimulated luminescence. Radiation Measurements 30(2): 207-217, DOI 10.1016/S1350-4487(99)00040-2.

Olley JM, Pietsch T and Roberts RG, 2004. Optical dating of Holocene sediments from a variety of geomorphic settings using single grains of quartz. Geomorphology 60: 337-358, DOI 10.1016/j.geomorph.2003.09.020.

Pan B, Pang H, Zhang D, Guan Q, Wang L, Li F, Guan W, Cai A and Sun X, 2015. Sediment grain-size characteristics and its source implication in the Ningxia-Inner Mongolia sections on the upper reaches of the Yellow River. Geomorphology 246: 255-262, DOI 10.1016/j.geomorph.2015.06.028.

Porat N, Amit R, Enzel Y, Zilberman E, Avni Y, Ginat H and Gluck D, 2010. Abandonment ages of alluvial landforms in the hyperarid Negev determined by luminescence dating. Journal of Arid Environments 74(7): 861-869. DOI 10.1016/j.jaridenv.2009.10.018.

Prescott JR and Hutton JT, 1994. Cosmic ray contributions to dose rates for luminescence and ESR dating: large depths and long-term time variations. Radiation Measurements 23(2-3): 497-500, DOI 10.1016/1350-4487(94)90086-8.

Ran L and Wang S, 2010. Study on channel evolution and hydraulic geometry in the Inner Mongolia reach of the Yellow River. Journal of Sediment Research (4): 61-67 (in Chinese), DOI 10.16239/j.cnki.0468-155x.2010.04.010.

Reimer PJ, Bard E, Bayliss A, Beck JW, Blackwell PG, Ramsey BC, Grootes PM, Guilderson TP, Haflidason H, Hajdas I, Hatte C, Heaton TJ, Hoffmann DL, Hogg AG, Hughen KA, Kaiser KF, Kromer B, Manning SW, Niu M, Reimer RW, Richards DA, Scott EM, Southon JR, Staff RA, Turney CSM and van der Plicht J,
2013. IntCal13 and Marine13 radiocarbon age calibration curves 0-50,000 years cal BP. Radiocarbon 55: 1869-1887.

Rhodes EJ and Bailey RM, 1997. The effect of thermal transfer on the zeroing of the luminescence of quartz from recent glaciofluvial sediments. Quaternary Science Reviews 16(3-5): 291-298, DOI 10.1016/S0277-3791(96)00100-X.

Rhodes EJ, 2011. Optically Stimulated Luminescence Dating of Sediments over the Past 200,000 Years. Annual Review of Earth and Planetary Sciences 39: 461-488, DOI 10.1146/annurev-earth040610-133425.

Richards BWM, Owen LA and Rhodes EJ, 2000. Timing of late quaternary glaciations in the Himalayas of northern Pakistan. Journal of Quaternary Science 15(3): 283-297, DOI 10.1002/(SICI)10991417(200003)15:33.3.CO;2-O.

Rittenour TM, 2008. Luminescence dating of fluvial deposits: applications to geomorphic, palaeoseismic and archaeological research. Boreas 37(4): 613-635, DOI 10.1111/j.1502-3885.2008.00056.x.

Roberts HM, 2007. Assessing the effectiveness of the double-SAR protocol in isolating a luminescence signal dominated by quartz. Radiation Measurements 42(10): 1627-1636, DOI 10.1016/j.radmeas.2007.09.010.

Roberts HM and Duller GAT, 2004. Standardised growth curves for optical dating of sediment using multiple-grain aliquots. Radiation Measurements $\quad 38(2): \quad 241-252, \quad$ DOI 10.1016/j.radmeas.2003.10.001.

Rodnight H, Duller GAT, Wintle AG and Tooth S, 2006. Assessing the reproducibility and accuracy of optical dating of fluvial deposits. Quaternary Geochronology 1(2): 109-120, DOI 10.1016/j.quageo.2006.05.017.

Schielein P and Lomax J, 2013. The effect of fluvial environments on sediment bleaching and Holocene luminescence ages-A case study from the German Alpine Foreland. Geochronometria 40(4): 283293, DOI 10.2478/s13386-013-0120-y.

Shi C, 2010. Changes in sediment accumulation in Ning-Meng reach of Yellow River in past over 500 years. Journal of Sediment Research 5: 19-25 (in Chinese).

Shields A, 1936. Anwendung der Ähnlichkeitsmechanik auf die Geschiebebewegung: Berlin, Preussische Versuchanstalt für Wasserbau und Schiffbau, Mitteilungen 26, 25.

Singarayer JS, Bailey RM, Ward S and Stokes S, 2005. Assessing the completeness of optical resetting of quartz OSL in the natural environment. Radiation Measurements 40(1): 13-25, DOI 10.1016/j.radmeas.2005.02.005.

Stokes S, Bray HE and Blum MD, 2001. Optical resetting in large drainage basins: tests of zeroing assumptions using single-aliquot procedures. Quaternary Science Reviews 20: 879-885, DOI 10.1016/S0277-3791(00)00045-7.

Stuiver M and Reimer PJ, 2013. Radiocarbon Calibration Program Calib Rev7.0.0

Ta W, Yang G, Qu J, Wang T and Dai FN, 2003. The effect of the coarse aeolian sand on siltation of the Inner Mongolian reach of the Yellow River. Environmental Geology 43: 493-502, DOI 10.1007/s00254-002-0666-0.

Ta W, Xiao H and Dong Z, 2008. Long-term morph dynamic changes of a desert reach of the Yellow River following upstream large reservoirs' operation. Geomorphology 97: 249-259, DOI 10.1016/j.geomorph.2007.08.008.

Ta W, Wang H and Jia X, 2011. Downstream fining in contrasting reaches of the sandbedded Yellow River. Hydrological Processes 25(4): 3693-3700, DOI 10.1002/hyp.8065.

Vandenberghe D, Derese C and Houbrechts G, 2007. Residual doses in recent alluvial sediments from the Ardenne (S-Belgium). Geochronometria 28: 1-8, DOI 10.2478/v10003-007-0024-z.

Wallinga J, 2002. Optically stimulated luminescence dating in fluvial deposits: A review. Boreas 31: 303-322, DOI 10.1111/j.15023885.2002.tb01076.x.

Wang S, Yan Y and Li Y, 2012. Spatial and temporal variations of suspended sediment deposition in the alluvial reach of the upper Yellow River from 1952 to 2007. Catena 92: 30-37, DOI 10.1016/j.catena.2011.11.012. 
Wintle AG, 1997. Luminescence dating: laboratory procedures and protocols. Radiation Measurements 27: 769-817, DOI 10.1016/S1350-4487(97)00220-5.

Wu J, Wang R and Yao J, 2006. Remote sensing monitoring and study on the change of the Yellow River course in Yinchuan plain sector. Remote Sensing for Land \& Resources 4: 36-40 (in Chinese), DOI 1001-070X(2006)04-0036-04.

Yang G, 2002. Identifying Sediment Sources and their Controls in the Inner Mongolian Reach of the Yellow River. Haiyang Publishing House: Beijing (in Chinese).

Yao Z, Ta W, Jia X and Xiao J, 2011. Bank erosion and accretion along the Ningxia-Inner Mongolia reaches of the Yellow River from 1958 to 2008. Geomorphology 127: 99-106, DOI 10.1016/j.geomorph.2010.12.010.

$\mathrm{Yu}$ L and Lai Z, 2012. OSL chronology and palaeoclimatic implications of aeolian sediments in the Qaidam Basin of the northeastern Qinghai-Tibetan Plateau. Palaeogeography, Palaeoclimatology, Palaeoecology 337: 120-129, DOI 10.1016/j.palaeo.2012.04.004.

Zhang J, Tsukamoto S, Grube A and Frechen M, 2014. OSL and ${ }^{14} \mathrm{C}$ chronologies of a Holocene sedimentary record (Garding-2 core) from the German North Sea coast. Boreas 43(4): 856-868, DOI 10.1111 /bor. 12071 . 